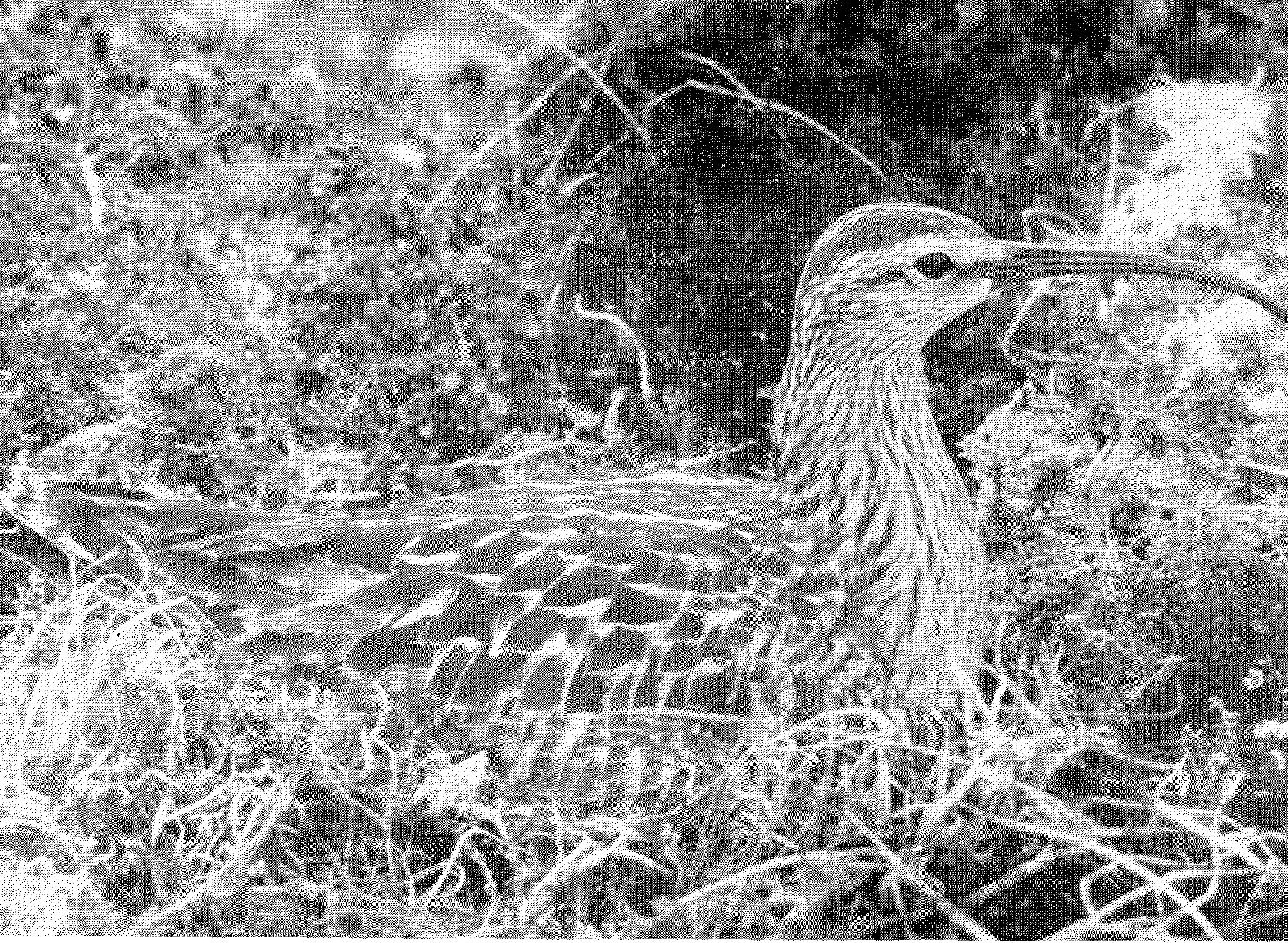

Bristle-thighed curlew photographed on nest some miles north of Mountain Village, Alaska. The down-curved beak is about five inches long.

$+$

\title{
THE SECRET OF THE BRISTLE-THIGHED CURLEW
}

\section{By Henry C. Kyllingstad}

\section{Introduction}

7 His story began in Tahiti a hundred sixty-three years ago with the discovery of a sickle-billed bird which was christened Numenius tabitiensis. Because it has hair-like modified feathers on its flanks and thighs, Numenius became known as the "bristle-thighed curlew", a name no neater than the Latin version. The present chapter of the story occurs on a wind-swept plateau in western Alaska.

Ornithologists combed the South Sea Islands for the curlew's nest, but none succeeded. Then in r 869 a single specimen was collected at Kenai, near Anchorage. This discovery gave rise to the hope that its nest might eventually be found in Alaska. Later other specimens were taken at points extending from Hooper Bay to the headwaters of the Colville River.

These records, discussion with Mr. Charles E. Gillham, formerly of the Fish and Wildlife Service, talks with Eskimos in the lower Yukon River region, and observation of the birds in their spring flights over 
Mountain Village led me to hope that I might be the fortunate one who would find the sought-after nest. H. B. Conover's description of the birds' calls ("The Game Birds of the Hooper Bay Region, Alaska", The Auk, vol. 43, 1926) enabled me to secure the migration records which, I think, were a strong link in the chain leading to the nest.

The curlew is about the size of a crow, but it is a slimmer model. Its wings, beak, neck, and legs are long and slender, and its beak is downcurved for about half of its five-inch length. The back is marked with tawny browns and buff; the underparts lighter with a few dark streaks on the flanks and more extending up the neck to the throat. The lower back and top of the tail are a light foxy-red. This tail coloring and the call are the best field marks. The well-known "wolf-call" heard on the city streets is a close enough imitation of the call to bring the birds wheeling about your head. The Eskimos call it "Chiu-eet".

\section{Investigations in Alaska, 1944-1947}

In following the various leads suggested by my Eskimo friends and the literature, I visited Kusilvak Mountain in 1944 and again the following year. Here I found no curlew, but near the peak I secured a pair of surf birds which I believe were about to nest. In I946, accompanied by John Stophlet of Toledo, Ohio, I visited the region of small volcanic hills east of Chevak, Alaska. It was here that Eskimo informants told Charlie Gillham the bird could be found. We were not successful, but because we were able to cover only a limited part of the area, we revisited it in 1947 , this time accompanied also by Mr. Warren, M. Petersen, U.S. Government teacher of Kalskag, Alaska, and my eight-year old son, David. We covered the area as well as possible on foot and with a small boat, but again had no success. After nearly three weeks in this area, we went to the eastern end of the Askinuk Mountains which extend inland from Scammon Bay to a distance of about thirty miles. Here again we found no curlew. We did gain field experience and eliminated for practical purposes large areas from subsequent search.

\section{Expedition}

On the strength of these four years of searching, together with a suggestion from Doctor George M. Sutton of the University of Michigan Museum of Zoology, I applied for a grant-in-aid from the Arctic Institute of North America in order to make a fifth attempt. By this spring the curlew's nest had become an obsession with me, so my wife says. I was extremely happy therefore, to receive a grant of $\$ 750$.oo. Warren Petersen agreed to come along, and later Dr. Arthur A. Allen of Cornell University asked if he might join our party. He brought assurance of funds from the National Geographic Society which we felt would be desirable if the Mountain Village area should be unproductive, in which case we 
hoped to continue northward into Seward Peninsula. We were happy, too, for the opportunity to work in the field with so famous an ornithologist.

Following agreements with the Arctic Institute, Dr. Allen, and the Alaskan "bush pilot" who was to carry us and our gear, we all settled back restlessly to await the spring breakup which would enable us to move into curlew country. During this time I readied my equipment, built a de-luxe bird blind complete with zippers, and marked an Alaska map with pins to show every place where the curlew had been found or collected. The pins indicated Mountain Village to be near the centre of the area.

\section{Search of the Igiak Bay Region}

On June second Dr. Allen, his son David, and Warren Petersen arrived from Bethel aboard Nat Browne's Alaska Airlines Bellanca. After a few days of conferences and preparation of supplies, we took.off on June fourth for the Igiak Bay region as Dr. Allen wished to secure photographs of the abundant wildfowl and shorebirds and we felt another search of the region would not be amiss. We made our camp at an unnamed lake at the base of a detached hill south of the main range. The inner end of Igiak Bay was visible from the top of our hill. The lower lands about us were largely tide flats.

This was indeed a bird paradise and a photographer's paradise too. Except for the occasional rain there was only one thing wrong-there were too many birds to photograph in the short time we planned to stay. In one week we photographed roughly thirty species at their nests.* In addition we had found nests of several other species and had blinds erected in readiness for more pictures.

We had decided to move two of our party to the hills north of Mountain Village on June eleventh. Dr. Allen and Warren wished to proceed with picture making at Igiak Bay, and so David Allen and I were to look over the Mountain Village spot to learn whether it would be worth the time of the entire party. This was the area that $W$ arren and $I$ had been interested in from the beginning as it was to these hills that all the migrant curlew had been headed.

Typical view of terrain north of Mountain Village, here a nest of the bristle-thighed curlew was first discovered in June 1948 . 
We made our camp on the shore of a large lake beside a mountain twenty miles from the village. This mountain is one of many that form a series of ridges extending northward into Seward Peninsula. Many small plateaus extend eastward from the higher hills.

\section{Discovery of the Nest}

On June twelfth there was a twenty mile wind from the east carrying with it a heavy drizzle mixed with patches of fog. Shortly before noon we decided to climb the mountain in spite of the weather. We tossed a coin which directed that David proceed south from the mountain top while I went north. I had gone about a half mile when I heard a loud, clear "piu-weet". This was it, and David knew it too as I had whistled imitations of the calls for him. I turned at the second whistle and saw a curlew leaving the middle of the plateau to head straight for David. The bird circled and called several times near him and then returned to the plateau. David headed for the ring of alders which separated the higher part of the hill from the plateau, and I cut across the brush-covered valley which lay between me and the curlew.

When I arrived at the edge of the plateau a half hour later, David was crouching behind some alders watching the centre of the plateau. A curlew paced across the open centre of the area. It seemed to confine its activity to the same general part of the plateau all of the time. We watched a while, whispered agreement on the likely location of the nest which we thought surely must be there, and then at a signal from David we rushed the spot. David had wisely removed his raincoat and high wading boots, and being considerably more of a runner than I, was soon ahead of me. The incubating bird flushed about thirty feet ahead of him and he reached the nest a few seconds before me.

Bristle-thighed curlew showing underpart of body. The nest is a slight depression with a few small pieces of lichen added.
Curlew on nest north of Mountain Village, Alaska, with newlyhatched, downy young.

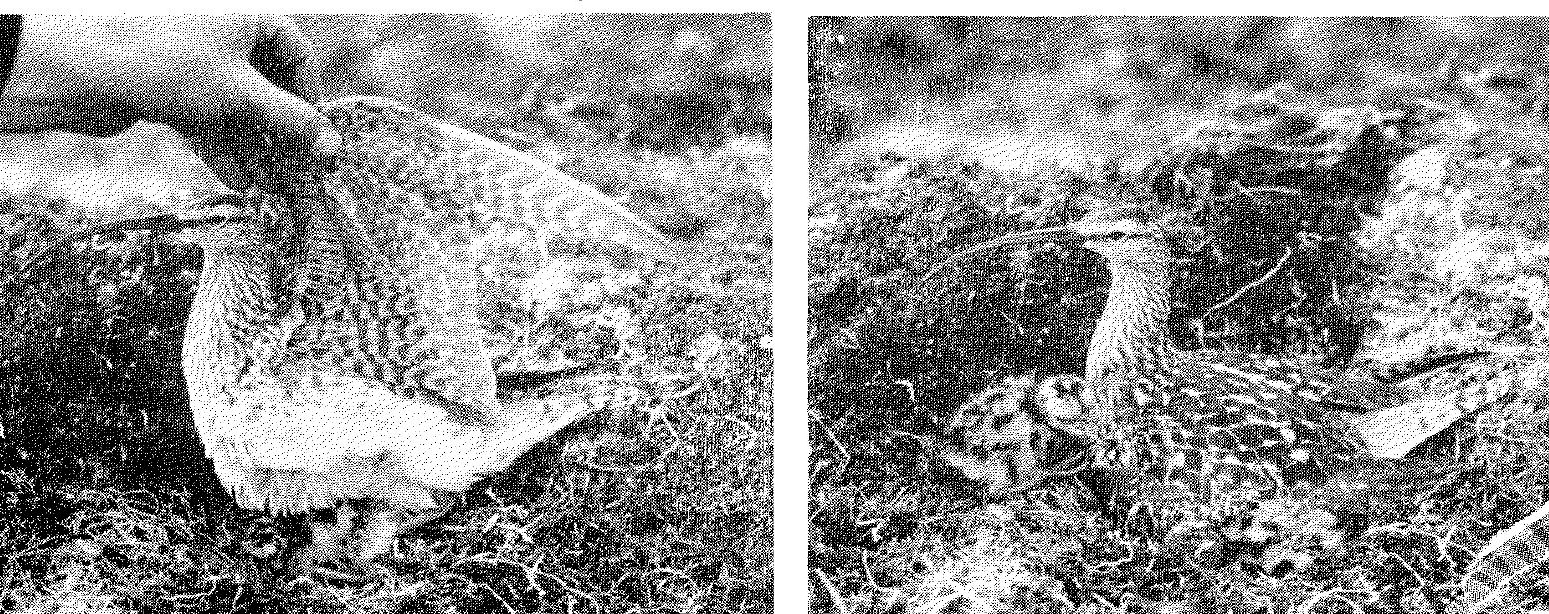


There it was! The long-kept secret of the bristle-thighed curlew. The nest was a simple depression at the edge of a large black lichen. It measured $6 \frac{3}{4}$ inches across by $2 \frac{1}{2}$ inches deep and contained four olive colored eggs marked chiefly about the large end with browns. A few small bits of yellow-green lichen appeared to be the only thing which the birds had added to the depression-no grasses or feathers lined it. Surrounding vegetation included moss azalea, crowberry, several forms of reindeer moss, a small sedge, and Labrador tea.

\section{Observation of Nest}

While we inspected the nest the parent birds circled about calling. Soon a long-tailed jaeger flew in from the north, and both birds took after it furiously. They were more than a match for this swift flier. The chase was a wild one indeed, and the curlews did not return until they had driven the jaeger more than a mile. We quickly set up my fancy zippered blind about twenty-five feet from the nest. While we were doing this a third curlew appeared and helped the others with their scolding. Because of the drizzle and poor light, and also because we wanted the birds to cover their nest before other jaegers appeared, we took no pictures but quickly left the plateau.

On the following day and every day until the young all hatched on the seventeenth, we returned to make pictures and notes. I secured the very first pictures in color and black and white on the thirteenth. The old birds quickly became so accustomed to our presence that we could photograph them at less than three feet without the use of the blind. We moved the blind closer-about six feet from the nest-and used it only when making moving pictures as the birds would return to the nest.more quickly if we were out of sight. Once on the nest however, they would allow a very close approach, in fact in order to make pictures of the return to the nest we had to almost lift the bird off.

On June fourteenth, Warren and Dr. Allen arrived from Igiak Bay. David and I tried to hide our excitement and simply told them that we thought the area looked good; worth a few more days anyway. Evidently we were not very good liars as the Doctor soon asked "What do you two have up your sleeves?" They could hardly believe us when we told them we had found the nest and so easily. We could hardly believe it ourselves.

\section{Discovery of Second Nest}

On the fifteenth all of the eggs had small cracks at the large end. On the same day Warren found a second nest on the next plateau to the southward. This nest contained only two eggs. We were unable to find any young about, though there may have been some, or the other eggs might have fallen to jaegers. In order to preserve one egg from the first 
nest in as good condition as possible Dr. Allen took the embryo out through a door cut in the side. Another egg he brought in to camp where he kept it in a pail with hot rocks in the bottom and a burlap cushion over them. At night he placed this egg in a tomato can with some cotton and took it into his sleeping bag. Two days later his foster-child hatched safe and sound and looked just like its brothers in the nest. This artificial incubation was necessary as the eggs could have hatched during our absence from the nest, in which case the old birds would have removed the shells, and our record of the nest would be incomplete. Fortunately all the remaining eggs hatched while we were present and we even secured motion pictures of the hatching and preserved all of the shells.

The parents were even tamer after the young hatched. The male bird allowed us to kill mosquitoes that were biting him about the face, to stroke his head and neck, and to lift his wings spreading the feathers beneath to record their color on movie film.

\section{Photographic Work}

Specimens including the parent birds from the first nest, the eggshells, a single downy young, and the nest itself are being sent to the U.S. National Museum. The other specimens will go to Cornell and other museums.

In the course of our work we saw as many as six curlew at one time. Every plateau extending eastward from the main range of hills appeared to have its pair of birds. David Allen who took few photographs and was able to scout around, saw as many as twenty individuals in a day. We believe that this entire range of hills may be so populated with curlew and probably constitutes the main breeding ground.

Few birds have ever been so thoroughly photographed. Four of us took still pictures in black and white and color and three of us made movies in color. Never have I had a more obliging subject for my cameras. If I live to be a hundred, I am sure I will never again have such an experience.

Our work at the curlew nest completed, we left on the twentieth for a somewhat anti-climactic additional week at Igiak Bay. We got a number of birds photographed that we had left undone on our first visit. Dr. Allen secured shots of the swans and godwits, both difficult and highly desirable subjects. On June 27 we returned to Mountain Village well content with the whole venture.

*Specimens included: Ruddy turnstone, Black turnstone, Spectacled eider, Emperor goose, Black-bellied plover, Cackling goose, White-fronted goose, Red-backed sandpiper, Pectoral sandpiper, Red phalarope, Northern phalarope, Alaska Yellow wagtail, Shortbilled gull, Glaucous gull, Sabine's gull, Little brown crane, Asiatic gyrfalcon, Red-throated loon, Arctic tern. 